\title{
PRELIMINARY OBSERVATIONS ON HABITAT USE PATTERNS OF THE MARINE TUCUXI, SOTALIA FLUVIATILIS, IN CISPATÁ BAY, COLOMBIAN CARIBBEAN COAST
}

\author{
Carolina García ${ }^{1 *}$ and Fernando Trujillo ${ }^{2}$
}

\begin{abstract}
Some aspects of the habitat use of Sotalia fluviatilis were monitored in the Cispatá Bay and adjacent coastal waters on the Atlantic Coast of Colombia, from November 1996 to August 1997. Dolphins were seen on 119 occasions during 1087.5 effort hours. They were present throughout the year, but entered the bay more often during the dry season, from December to April $\left(X^{2}=262.42, \mathrm{p}<0.05\right)$. Most of their time was spent feeding $(54 \%)$ and travelling/feeding $(23 \%)$. Travelling and travelling/ feeding decreased respectively from $21 \%$ to $14 \%$, and from $41 \%$ to $6 \%$ during the rainy season. We interpreted this change in behaviour as dolphins spending more time searching for food during the dry season. S. fluviatilis entered the bay in groups of about ten individuals $(S D=8.6)$ and stayed within the bay for about 81.5 minutes $(S D=57.9)$. Dolphin presence was significantly higher during the morning than in the afternoon $(\mathrm{H}=11.7 ; \mathrm{p}<0.05)$. In general, no preferential area within the bay was observed, but a seasonal difference in time spent in different zones was detected. We suggest that habitat use patterns depend mainly on resource availability and distribution. Boat traffic was significantly higher during the tourist season $(t=4.1, p<0.05)$, but dolphin presence was independent of boat traffic $\left(X^{2}=0.002, p=0.96\right)$. They did not avoid high traffic zones, but they changed their behaviour or the direction of movement in the presence of boats in six out of nine occasions. The main pressures on the local population of S. fluviatilis were identified as: 1) High speed boat traffic inside the bay. 2) Accidental mortality in fishing gears. 3) Indirect pressure from fisheries that have depleted the marine resources and have caused habitat degradation.

Resumen - Desde noviembre de 1996 hasta agosto de 1997 se estudiaron algunos aspectos de la utilización de la bahía de Cispatá, Costa Atlántica colombiana, por parte de los bufeos grises (Sotalia fluviatilis). Los delfines se observaron en 119 ocasiones de 1087.5 horas de esfuerzo. Los bufeos estuvieron presentes durante el año entero, pero entraron a la bahía con mayor frecuencia durante la estación seca, de diciembre a abril $\left(X^{2}=262.42, p<0.05\right)$. La mayor parte de su tiempo fue invertida en alimentación (54\%) o en una combinación de desplazamiento y alimentación (23\%). Durante la época seca los delfines invirtieron más tiempo en actividades de desplazamiento (21\%) y alimentación/desplazamiento (41\%), que en época de lluvias (14\% y 6\% respectivamente). Esta diferencia estacional en el comportamiento se interpretó como un mayor tiempo de búsqueda de alimento cuando el recurso íctico parece más escaso. Los delfines entraron en grupos de aproximadamente diez individuos $(S D=8.6)$ y permanecieron dentro de la bahía durante aproximadamente 81.5 minutos $(S D=57.9)$. La presencia de delfines fue significativamente más alta durante la mañana que en las horas de la tarde $(\mathrm{H}=11.7 ; \mathrm{p}<0.05)$. No se encontró una zona de mayor preferencia a lo largo del año, aunque sí hubo una diferencia estacional en este aspecto. En general, los patrones de uso de hábitat y sus variaciones estacionales deben estar relacionados con la disponibilidad y distribución de los recursos. El tránsito de botes es mayor durante la alta temporada turística $(t=4.1, p<0.05)$, pero la presencia de delfines es independiente de la temporada $\left(X^{2}=0.002, p=0.96\right)$. Sin embargo, los delfines cambiaron su comportamiento o la dirección de desplazamiento en seis ocasiones de nueve. Se identificaron las siguientes presiones sobre la población de bufeo gris: 1) el tránsito de botes a altas velocidades dentro de la bahía. 2) La mortalidad accidental en artes de pesca. 3) La deterioración del medio ambiente y sobreexplotación de los recursos marinos por las actividades pesqueras.
\end{abstract}

Keywords: Sotalia fluviatilis, tucuxi dolphins, ecology, habitat use, Cispatá Bay, Colombia.

\section{Introduction}

Tucuxi dolphins, Sotalia fluviatilis, are endemic to South and Central America with two recognised ecotypes (da Silva and Best, 1994) or species (Monteiro-Filho et al., 2002). The fluvial form is distributed along the Amazon basin while the marine form is found from southern Brazil to Honduras (da Silva and Best, 1994). Although the number of studies on this species has increased in recent years (e.g. da Silva and Best, 1994; Ramos et al., 2000; Rosas, 2000; Santos et al., 2001; Monteiro-Filho et al., 2002; Flores, 2003), knowledge of tucuxis is still scarce and they remain classified as "Data Deficient" by the IUCN (Reeves et al., 2003). In 1994 the Omacha Foundation started a project to investigate the ecology of dolphin populations in the Morrosquillo Gulf, Colombian Caribbean coast. Of the five dolphin species reported from this coast (Prieto, 1988), only two enter Cispatá Bay: Bottlenose dolphins (Tursiops truncatus) and the marine tucuxi, locally known as "bufeo gris" (Avila, 1995). Avila (1995) determined that the most common dolphin species was S. fluviatilis and that Cispatá Bay was particularly important for feeding purposes. Based on his results, the Omacha Foundation Project was designed to determine the importance of Cispatá Bay for both species populations, in an area where social and economic problems lay a hard pressure on the environment.

This study focused on seasonal and daily use of the area, distribution of group sizes and behaviour of tucuxis in Cispatá Bay. In addition, the influence of boat traffic on dolphin habitat use was preliminarily explored and other potential threats were identified.

\section{Material and Methods}

\section{The study area}

Cispatá Bay (Figure 1) is located southwest of the Gulf of Morrosquillo on the Colombian Atlantic coast $\left(9^{\circ} 23^{\prime} \mathrm{N}\right.$, $\left.75^{\circ} 49^{\prime} \mathrm{W}\right)$. It covers an area of approximately $10 \mathrm{~km}^{2}$ with an average depth of about two metres, ranging from one

\footnotetext{
${ }^{1}$ Carrera 4 \# 71-61 apt. 1001, Bogotá, Colombia. E-mail: garciaimhof@hotmail.com

${ }^{2}$ Fundación Omacha. Cra 7 \# 27-40 Piso 4, Bogotá, Colombia.

${ }^{*}$ Corresponding author.
} 
to six metres (Avila, 1995). It is characteristically an estuary surrounded by a vast mangrove system connected to the Sinú River by a number of small channels and marshes. The river mouth is approximately $15 \mathrm{~km}$ northwest of the bay. Both estuarial and mangrove systems are of high productivity (Prahl, 1989; Levinton, 1995). In this area in particular, red mangroves (Rhizophora mangle) offer habitat, protection and act as a nursery area to a variety of aquatic organisms (Sierra, 1996; Invemar, 1999). It is possible that the availability of this kind of habitats and fresh water sources is determining the general distribution of the marine tucuxi, as suggested by Edwards and Schnell (2001). The bay has mainly estuarial characteristics during the rainy season (May - November), while low precipitation from December to April makes the characteristics of the bay more similar to a marine environment (Table 1).

\section{Data collection and analyses}

Observations were made from a two metre-high tower in the northwest part of the bay entrance. From that point, most of the bay could be monitored, except for the innermost zone A (Figure 1), as high mangroves blocked the view. Approximately $4.5 \mathrm{~km}^{2}$ of adjacent areas to the east and northeast of the observation point were also monitored.

Data were recorded on 176 days from November 1996 to August 1997. Daily observation effort was approximately six hours between 6:00 and 18:00. Dolphin groups were usually observed with the naked eye and, if too far, with the aid of $9-32 \times 50 \mathrm{~mm}$ binoculars.
Whenever dolphins were sighted, data on species, time of day, behaviour, group size, location and movements were recorded. In addition to dolphin data, salinity and water temperature were recorded every hour to analyse daily and seasonal differences in environmental features. Salinity was measured with a $0.1 \mathrm{ppt}$ precision electronic salinometer and temperature was measured with a $1^{\circ} \mathrm{C}$ precision thermometer.

Tucuxi presence throughout the year was explored by comparing number of sightings for dry and rainy seasons (Mann-Whitney test). Proportions of time the dolphins spent inside and outside the bay were corrected according to area size. A contingency table was used to test for independence between seasons and the proportion of time dolphins spent inside and outside the bay.

Behaviour categories were adapted from Shane (1990) as: (F) feeding, (T) travelling, (T/F) travelling/feeding and (S) any behaviour that included socialising. Other categories were not seen and therefore not considered in the analysis. A group was defined as an aggregation of dolphins, moving in the same general direction and usually engaged in the same activity (Shane, 1990). Considering the group as a unit, we used a focal continual method (Altmann, 1974; Martin and Bateson, 1986). The first instance a behaviour category was seen corresponded to the start time and its duration lasted until another category was detected. If dolphins were lost between different activities, these data were not considered. ANOVA was used to look for seasonal differences in time budgets.

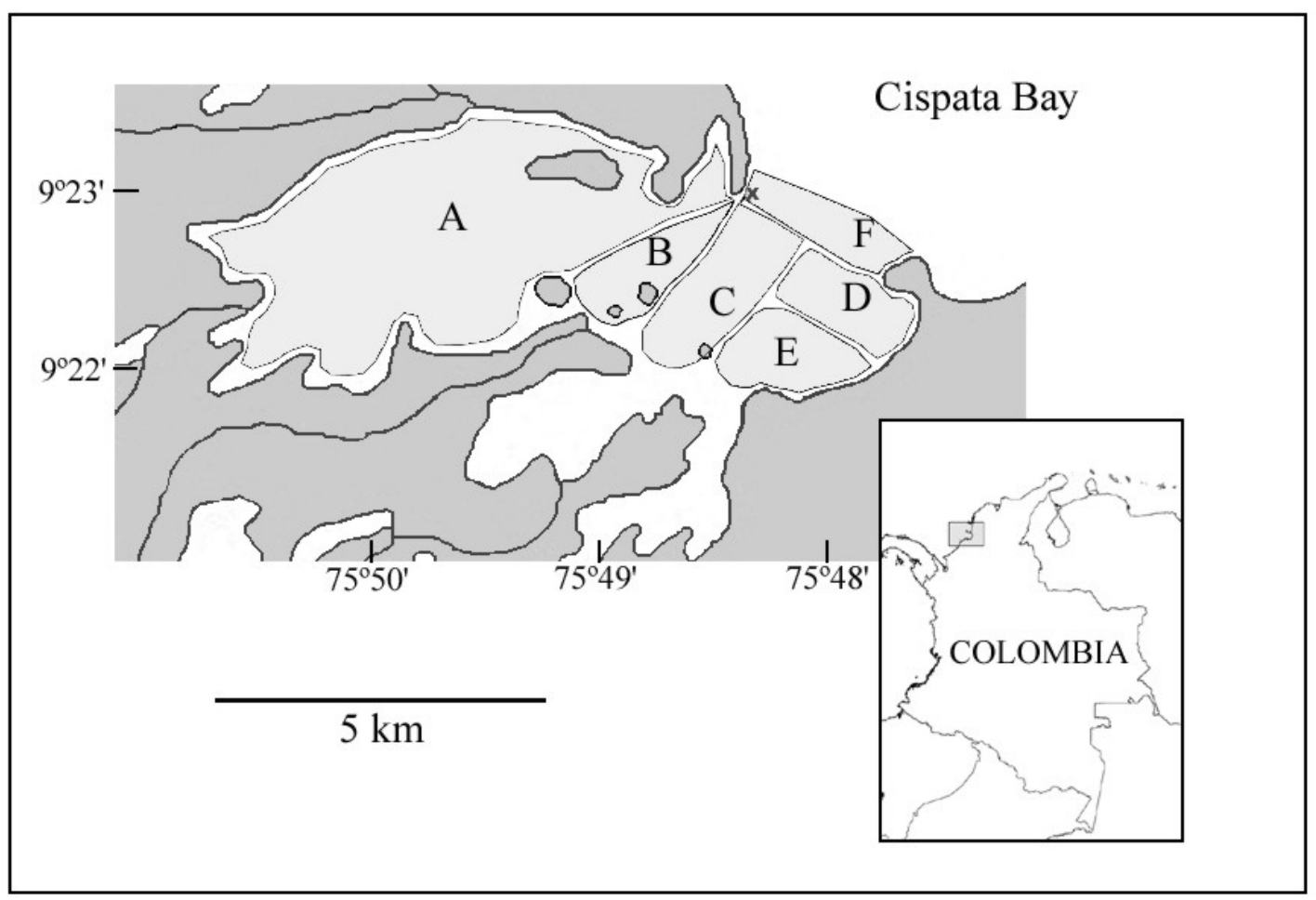

Figure 1. Map of Cispatá Bay study area in the Caribbean coast of Colombia, showing defined research zones. The observation point is indicated by the $\mathrm{x}$. 
Group size was classified into five categories: (G1) 1-5 individuals, (G2) 6-10 individuals, (G3) 11-15 individuals, (G4) 16-20 individuals and (G5) more than 20 individuals. A Kruskal-Wallis test permitted seasonal comparison of group sizes.

The observation time between 6:00 and 18:00 was divided into two-hour periods. Time of residence in each period was divided by observation effort and a Kruskal-Wallis test was used to find patterns of diurnal presence.

The bay was divided into six zones of different shape and size, limited by natural land-marks (Figure 1). These zones corresponded approximately to those mentioned by Avila (1995) as distinctive areas of residence, thus allowing comparison of both studies. The characteristics of each zone are summarised in
Table 2. Total time of residence in each zone was divided by zone size and compared with a chi-square test. Dolphins used three entrance/exit routes referred to as north, middle and south routes. Independence between route and zones visited was tested with a contingency table.

Number of boats was corrected for by observation effort and compared between high and low tourist season via a t-student test. To determine if boat traffic affected tucuxis, number of sightings was contrasted between high and low tourist seasons (June - July). Additionally, behaviour in the presence of boats within $200 \mathrm{~m}$ from the group was sampled ad libitum as: changes in behaviour or direction, "positive" interaction (e.g. approaching the boat, bow-riding) or no apparent reaction.

Table 1. Monthly records of effort, tucuxi sightings and environmental conditions from November 1996 to August 1997, in Cispatá bay, Caribbean coast of Colombia.

\begin{tabular}{lrrrrrrrrr}
\hline \hline & NOV 96 & DEC 96 & FEB 97 & MAR 97 & APR 97 & MAY 97 & JUN 97 & JUL 97 & AUG 97 \\
\hline \hline Effort hours & 140.7 & 57.3 & 47.3 & 97.9 & 156.2 & 142.8 & 150.3 & 141.9 & 153.3 \\
Tucuxi sightings & 3 & 2 & 5 & 10 & 21 & 21 & 24 & 16 & 17 \\
Number of dolphins & 44 & 23 & 80 & 102 & 101 & 166 & 132 & 178 & 117 \\
Time with dolphins (hours) & 4.7 & 3.1 & 5.6 & 7.9 & 12.7 & 13.9 & 5.0 & 11.6 & 6.2 \\
Sightings/hour & 0.02 & 0.03 & 0.11 & 0.10 & 0.13 & 0.15 & 0.16 & 0.11 & 0.11 \\
Dolphins/hour & 0.31 & 0.40 & 1.69 & 1.04 & 0.65 & 1.16 & 0.88 & 1.25 & 0.76 \\
Average salinity (ppt) & - & - & 24 & 25.0 & 24.6 & 23.5 & 23.3 & 22.2 & 22.3 \\
Average water temperature ( $\left.{ }^{\circ} \mathrm{C}\right)$ & 28.3 & 27.7 & 28.1 & 27.6 & 27.4 & 28.3 & 28.0 & 28.2 & 28.3 \\
Rains (mm) & $126.9^{*}$ & $46.2^{*}$ & 0 & 0 & 99 & 69 & 205 & 221 & 88 \\
\hline \hline
\end{tabular}

(*) 1970-1995 average values.

Table 2. Characterisation of zones in Cispatá bay.

\begin{tabular}{|c|c|}
\hline ZONE & CHARACTERISTICS \\
\hline A & $\begin{array}{l}\text { Highest influence of the river, surrounded by } \\
\text { mangroves, low boat traffic. }\end{array}$ \\
\hline B & $\begin{array}{l}\text { Several mangroves around and presence of a } \\
\text { sand bank. Influence of an artisanal fish and } \\
\text { shrimp aquaculture. Low boat traffic. }\end{array}$ \\
\hline $\mathrm{C}$ & $\begin{array}{l}\text { Central zone, few mangroves and influence of } \\
\text { gulf waters. Low boat traffic. }\end{array}$ \\
\hline $\mathrm{D}$ & $\begin{array}{l}\text { Higher boat transit, influence of the } \\
\text { fishermen's port and the tourist complex } \\
\text { "Cispata Marina \& Hotel". Few mangroves } \\
\text { left. Gulf waters influence. }\end{array}$ \\
\hline E & $\begin{array}{l}\text { Lowest boat transit. Influence both from } \\
\text { channels and gulf waters. It has got some } \\
\text { mangroves and a small sand beach. }\end{array}$ \\
\hline F & $\begin{array}{l}\text { Bay entrance, influence of gulf waters and } \\
\text { almost no mangroves. Biggest depths in the } \\
\text { whole area and high boat transit. }\end{array}$ \\
\hline
\end{tabular}




\section{Results}

During 1087.5 hours of observation, S. fluviatilis was sighted on 119 occasions for a total of 75.3 hours. Bottlenose dolphins were seen on only 16 occasions and therefore were not considered in the analyses.

Tucuxi sightings were similar for dry and rainy seasons $(\mathrm{U}=33, \mathrm{p}=0.88)$, (Table 1$)$. Dolphins spent longer periods inside the bay during the dry season $(84.5 \%$ out of 29.4 hours of direct observation) than during the rainy season ( $66.9 \%$ out of 45.9 hours of direct observation). This difference was significant $\left(X^{2}=262.42, \mathrm{p}<0.05\right)$.

In general, feeding (54\%) and travelling/feeding (23\%) were more common than travelling alone $(17 \%)$ and socialising (6\%). Travelling and travelling/feeding were more common during the dry season than the rainy season $(\mathrm{F}=5.6$, d.f. $=102, \mathrm{p}<0.05)$, (Figure 2$)$.

In $64.5 \%$ of the sightings, group size was equal to or fewer than ten individuals with an average of 10.5 (SD = 8.6). Seasonal differences in group size were not significant ( $F$ $=1.9$, d.f. $=24, p=0.18$ ), but there was a trend of increasing group size during the rainy season (Figure 3).

Tucuxis entered the bay significantly more often before midday ( 0.16 sightings/hour, $\mathrm{SD}=0.02)$ than in the afternoon (0.09 sightings/hour, $\mathrm{SD}=0.03),(\mathrm{H}=11.7 ; \mathrm{p}<0.05)$. Mean time of residence inside the bay was 81.5 minutes $(S D=57)$. No seasonal difference for the diurnal pattern $(\mathrm{H}=8.4 ; \mathrm{p}=$ $0.14)$ or for time of residence $(U=79 ; p=0.59)$ was detected. All zones were frequented for similar lengths of time, except for zone $\mathrm{C}$, visited for significantly shorter periods
$(\mathrm{H}=19.7 ; \mathrm{p}<0.05)$. A seasonal difference was detected: Zone A was frequented for longer periods during the rainy season whereas Zone $\mathrm{E}$ was visited longer during the dry season $\left(X^{2}=13.9, p<0.05\right)$. We also found that animals preferred to use certain zones depending on their entrance route. When they entered through the south route, they usually spent more time in Zones D and E, but when they entered through the north route, they visited Zones $\mathrm{A}$ and $B$ for longer periods $\left(X^{2}=20.5, p<0.05\right)$. Zone $C$ visits were independent of entrance/exit routes. The middle route was used to visit any zone within the bay and dolphins used the latter more than four times as much as the other routes. Boat traffic increased during the high tourist season from $3.7(\mathrm{SD}=1.4)$ to $5.1(\mathrm{SD}=1.7)$ boats per hour $(\mathrm{t}=4.1, \mathrm{p}<$ $0.05)$. Tucuxi presence, however, was not different between tourist seasons $\left(X^{2}=0.002, p=0.96\right)$ and dolphins did not avoid high transit zones. On the other hand, changes in behaviour and/or direction of movement were detected on six out of nine occasions and only once did they interact "positively" with a motor boat (following its wake).

\section{Discussion}

\section{Seasonal distribution}

Tucuxis were present throughout the year in Cispatá Bay and adjacent coastal waters, but there was a seasonal variation in distribution. During the rainy season dolphins were more dispersed in areas in the vicinity of the bay, whereas during the dry season they entered the bay more

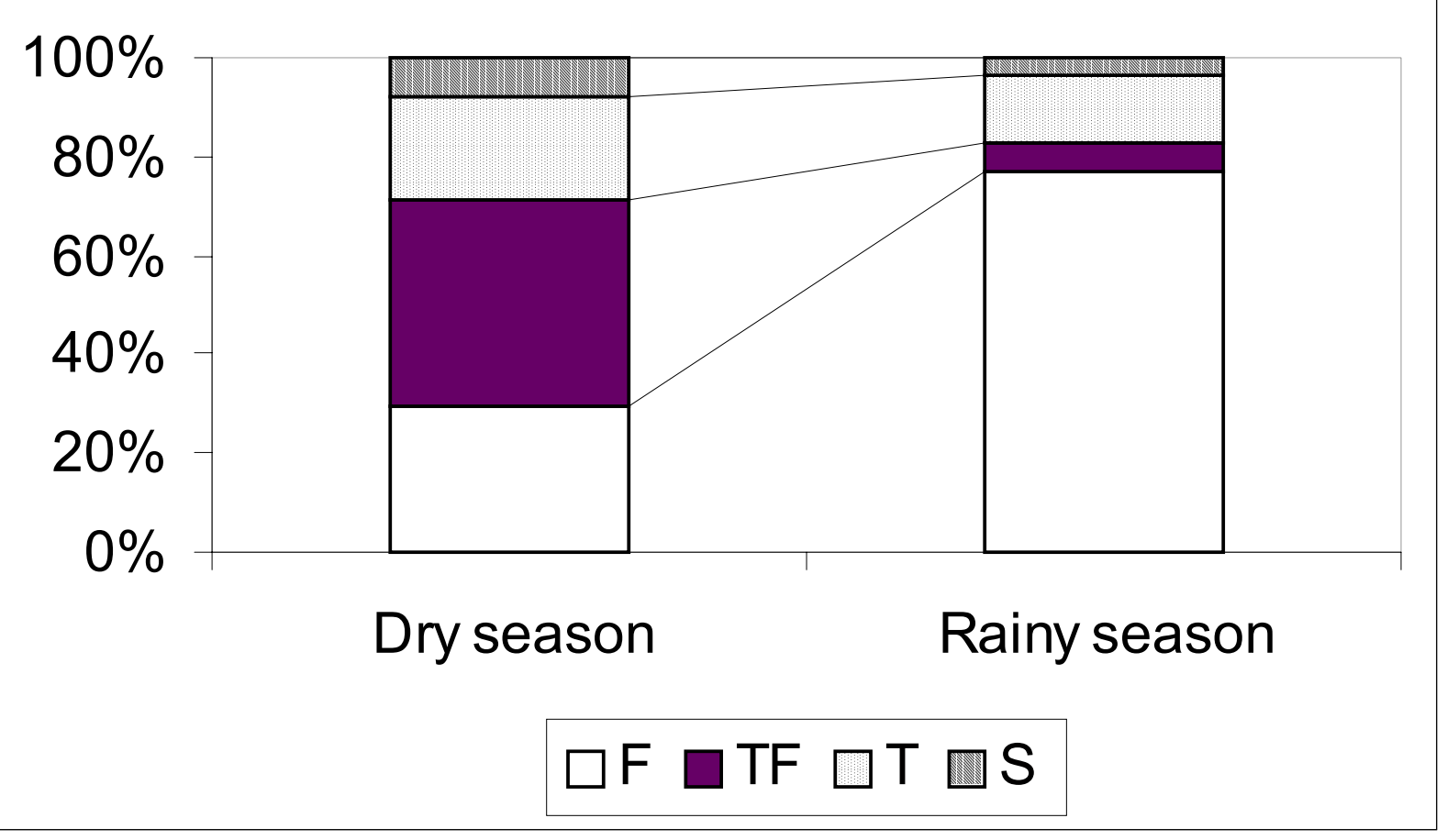

Figure 2. Differences in time budgets of Sotalia fluviatilis in Cispatá Bay $(\mathrm{p}<0.05)$. (F) feeding, (TF) travelling/feeding, (T) travelling, (S) any behaviour that included socialisation. 


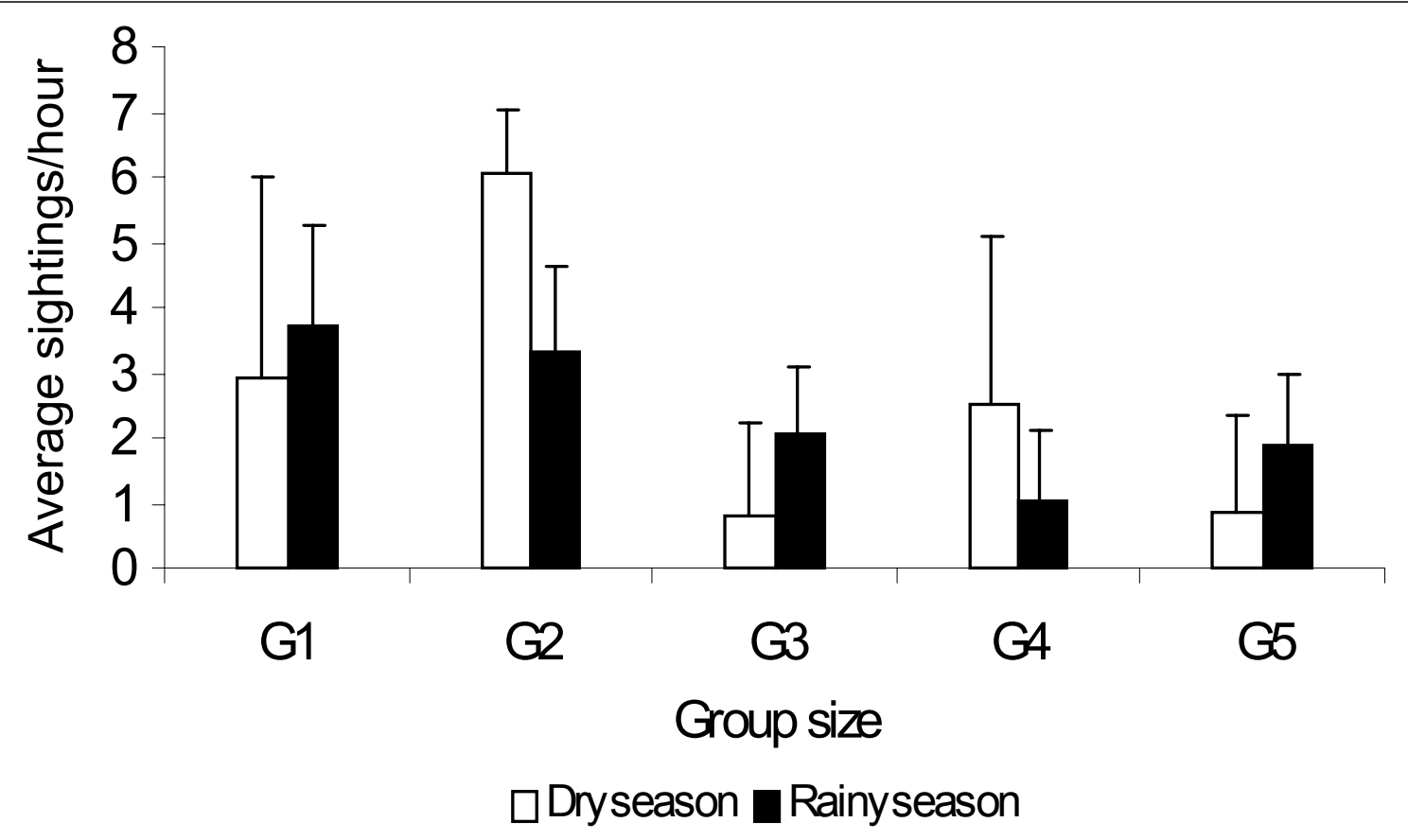

Figure 3. Distribution of group size classes of Sotalia fluviatilis in Cispatá bay. (G1) 1-5 individuals, (G2) 6-10, (G3) 11-15, (G4)16-20, (G5) $>20$ individuals. Error bars show standard deviation.

often. Avila (1995) also studied the presence of dolphins in this bay and adjacent areas through boat surveys covering coastal waters up to $2 \mathrm{~km}$ off the coast to the north and west of the bay. He found the similar pattern, with more frequent sightings of tucuxis inside or near the bay during the dry season, whereas during the rainy season dolphins were more scattered throughout the whole study area.

Seasonal variability in estuary conditions determines differences in fish species composition, abundance and distribution (Sierra, 1996; INVEMAR, 1999; Blanco, 2001). According to (Blanco, 2001) and local fishermen, fish are more abundant during the rainy season and fish sizes are larger outside the bay (Blanco, 2001). Availability of some fish species, such as Eugerres plumieri, is fairly constant throughout the year inside the estuary (Parra, 1996). This species is part of tucuxi's diet (Avila, 1995). It is possible that dolphins depend more on the bay's constant food availability during the dry season when fish is scarcest outside the bay (Sierra, 1996).

Behaviour

The importance of the bay as a feeding area is also supported by the behavioural data. Dolphins spent $77 \%$ of their time in activities that involved feeding (Figure 2). Socialisation was uncommon and resting was never observed. Avila (1995) sampled tucuxi behaviour ad libitum, both inside the bay and surrounding coastal waters, and found that dolphins were feeding $38 \%$ of the time. Low rates of socialising and resting are probably due to the combination of small area size and shallow depth, as well as due to human activities (see conservation aspects below).

Seasonal differences in dolphin behaviour might result from varying availability and distribution of prey. We suggest that the high rate of travelling and travelling/ feeding during the dry season reflects a need to search more thoroughly for fish when the resource is more limited.

A trend to increase group size during the rainy season (Figure 3; Avila, 1995) might also reflect resource variability throughout the year. Presence of larger groups may be explained by increased fish abundance during the rainy season and by the fact that during this season fish move predominantly in schools (Blanco, 2001). Fish schools would be more efficiently herded by larger dolphin groups (Norris and Shilt, 1988). Co-operative feeding is slightly more frequent during the rainy season inside the bay (García, unpublished data), which also suggests that larger fish schools might be preyed upon during this time of the year.

\section{Daily patterns}

Results from this study and from Avila (1995) showed that tucuxis prefer the morning hours to enter Cispatá Bay. Although habitat partitioning between S. fluviatilis and T. truncatus may occur in this area (García, 2001³), diurnal patterns of presence are probably related to

\footnotetext{
${ }^{3}$ García, C. (2001) Habitat use of Sotalia fluviatilis and Tursiops truncatus (Colombia). Page 79 in Abstracts XIV Biennial Conference on the Biology of Marine Mammals, 28 November-3 December, Vancouver, Canada.
} 
other factors as tucuxi preferences did not change when bottlenose dolphins were absent.

Tucuxis remain inside the bay for relatively short periods in comparison with studies carried out elsewhere. For example, tucuxi dolphins spend up to ten hours or more inside Norte Bay, southern Brazil (Flores, 1992) and Guanabara Bay, southeastern Brazil (Geise, 1991). These bays, however, are deeper and larger than Cispatá Bay. Moreover, in those and other bays dolphins use the area to feed, rest and / or socialise (Lodi and Fiori, 1985; Geise, 1989; Flores, 1992; Norris et al., 1994), Daily patterns, time spent in each zone and total time inside the Cispatá Bay, are probably determined by habit use (i.e. feeding, resting, socialising or travelling), area size, biotic (e.g. presence of prey, predators or competitors) and abiotic characteristics. It is likely that dolphins spent relatively short periods inside Cispatá Bay because the area was used only for foraging purposes.

\section{Conservation aspects}

The importance of Cispatá Bay for the tucuxi population was evident in all studied aspects. The area however, is being exposed to several threats:

-Boat traffic is relatively low most of the time, but during the tourist season it increases and boats travel very often at high speeds. The Hotel and Marina Cispatá, which is expending will contribute to aggravate this problem, by increasing the number of high-speed boats in the area. Dolphin presence did not vary significantly between high and low tourist seasons and they did not show preference for zones with fewer boats. Nevertheless we detected changes of behaviour or direction of movement on several occasions. Avila (1995) also observed several boat evasion strategies. Because of the shallowness of the bay, there is little room for boat evasion by diving deeper (Avila, 1995).

-Tucuxis are occasionally entangled in gillnets (Avila, 1995) of varying lengths (200 to $800 \mathrm{~m}$ ) that are often left overnight. This is probably the most common problem affecting riverine (Beltrán, 1998) and coastal S. fluviatilis (e.g. Barros and Texeira, 1994; Avila, 1995; Rosas, 2000; Edwards and Schnell, 2001; Flores, 2002) populations. Local people usually do not take dolphins intentionally, but incidentally caught dolphins are often consumed (author's pers. obs.).

-Industrial and artisanal fisheries are not regularly monitored and there are few available data on landings and virtually no data on catch per unit effort (CPUE). Even with such poor information, the national institute for marine and coastal research (INVEMAR, 2003; available at www.invemar.org.co) recognises that many species are under high risk of over-harvesting. Non-commercial and under-sized commercial species are being wasted by non-selective fishing (Blanco, 2001; Rueda and Defeo, 2003). Economical pressures are forcing local fishermen to increase fishing effort, to introduce more aggressive methods (less selective fishing methods, reduced mesh size) and to ignore area closures and minimum fish size limits (Blanco, 2001).

Cispatá Bay used to be an important feeding area for tucuxi dolphins until at least few months after the period of this study. Recent studies, however, have shown that dolphins no longer frequent the bay (Dussán-Duque, $2003^{4}$ ). This author suggests that changes in habitat may have caused this distribution shift. We believe that the main threat to the ecosystem in general and to dolphins in particular is the depleted marine resources due to over-fishing. Landings from one of the local fishing companies show a sharp decrease from 1993 until 1997 (Tesalia-Marina Ltd., unpublished data). Fisheries analyses in Colombia do not currently estimate CPUE, and total landings alone do not show the real status of fisheries (Levinton, 1995). We therefore recommend methodical research on ecological and economical aspects of the fishery Legislation concerning fisheries should be revised and enforced in order mitigate bycatch and to recover depleted fish stocks. A major conservation and education project should be designed for local people to explore sustainable fishing methods and alternative economical activities.

\section{Acknowledgements}

This project was supported by OCENSA. We wish to thank Jairo Aguilera, Gerardo Viña, Rodolfo Hinestroza and many local people for their cooperation during the field work, and the following people for comments on early versions of this article: Jose Manuel Avila, Joseph Cheer, Gordon Hastie. Christoph Richter and two anonymous referees provided valuable comments to improve this article.

\section{References}

Altmann, J. (1974) Observational study of behaviour: sampling methods. Behaviour 49: 227-267.

Avila, J.M. (1995) Aspectos biológicos y etológicos de delfines costeros con énfasis en Sotalia fluviatilis en la Bahía de Cispatá, Atlántico Colombiano. Bachelor Dissertation, Universidad Jorge Tadeo Lozano, Bogotá.

Barros, N.B. and Teixeira, R.L. (1994) Incidental catch of marine tucuxi, Sotalia fluviatilis, in Alagoas, Northeastern Brazil. Report International Whaling Commission (Special Issue 15): 265-268.

Beltrán, S. (1998) Captura accidental de Sotalia fluviatilis (Gervais, 1853) na pescaria artesanal do Estuário Amazônico. Master Dissertation, INPA, Manaus.

${ }^{4}$ Dussán-Duque, S. (2003) Preliminary results of the distribution and habitat use of coastal Sotalia (Sotalia fluviatilis) in the Gulf of Morrosquillo, Colombia. Page 45 in Abstracts XV Biennial Conference on the Biology of Marine Mammals, 14-19 December, Greensboro, USA. 
Blanco, Y.A. (2001) Caracterización de las pesquerías en Cispatá y Caño Lobo en el golfo de Morrosquillo (Caribe colombiano). Bachelor Dissertation, Universidad del Magdalena, Santa Marta.

da Silva, V.M.F. and Best, R.C. (1994) Tucuxi Sotalia fluviatilis (Gervais, 1853). Pages 43-69 in Ridgway, S.H. and Harrison, R. (Eds) Handbook of Marine Mammals. Academic Press, San Diego.

Edwards, H.H. and Schnell, G.D. (2001) Status and ecology of Sotalia fluviatilis in the Cayos Miskito Reserve, Nicaragua. Marine Mammal Science 17: 445-472.

Flores, P.A. (1992) Observaçoes sobre comportamento, movimentos e conservaçâo do golfinho ou boto Sotalia fluviatilis (Gervais, 1853) (Mammalia, Cetacea, Delphinidae) na Baía Norte de Santa Catarina, SC, Brasil. Bachelor Dissertation, Universidad Federal de Santa Catarina, Florianópolis.

Flores, P.A.C. (2002) Tucuxi Sotalia fluviatilis. Pages 1267-1269 in Perrin, W.F., Würsig, B. and Thewissen, H.G.M. (Eds) Encylopedia of Marine Mammals. Academic Press, San Diego.

Flores, P.A.C. (2003) Ecology of the marine tucuxi dolphin (Sotalia fluviatilis) in southern Brazil. Doctoral Thesis, Pontifícia Universidade Católica do Rio Grande do Sul, Porto Alegre, Brazil.

Geise, L. (1989) Estrutura social, comportamental e populacional de Sotalia sp. (Gray, 1886) (Cetacea, Delphinidae) na região estuarinolagunar de Cananeia, SP e na Baía de Guanabara, RJ. Master Dissertation, University of São Paulo.

Geise, L. (1991) Sotalia guianensis (Cetacea, Delphinidae) population in the Guanabara Bay, Rio de Janeiro, Brazil. Mammalia 55: 371-379.

INVEMAR (1999) Proyecto Evaluación Ecológica del Antiguo Delta del Río Sinú. Invemar, Santa Marta, Colombia: 168p.

INVEMAR (2002) Informe del Estado de los Ambientes Marinos y Costeros de Colombia: Año 2002. Invemar, Santa Marta, Colombia: $275 p$.

Levinton, J.S. (1995) Marine biology. Function, biodiversity, ecology. Oxford University Press, Oxford

Lodi, L. and Fiori, B. (1985) Observações sobre o comportamento de golfnho rotador Stenella longirostris (Cetacea, Delphinidae) na ilha de Fernando de Noronha-Brasil. Grupo de Mamíferos Aquáticos. Rio de Janeiro, Fundação Brasileira para a Conservação da Natureza-FBCN.

Martin, P. and Bateson, P. (1986) Measuring behaviour. Cambridge University Press, Cambridge.

Monteiro-Filho, E.L.A., Monteiro, L.R. and Reis, S.F.d. (2002) Skull shape and size divergence in dolphins of the genus Sotalia: A tridimensional morphometric analysis. Journal of Mammalogy 83: $125-134$
Norris, K. and Schilt C. (1988) Co-operative Societies in ThreeDimensional Space: On the Origins of Aggregations, Flocks, and Schools, with Special Reference to Dolphins and Fish. Ethology and Sociobiology 9: 149-179.

Norris, K.S., Würsig, B., Wells, R.S. and Würsig, M. (1994) The Hawaiian spinner dolphin. University of California Press, Los Angeles.

Parra, G.J. (1996) Biología de la mojarra rayada, Eugerres plumieri (Cuvier, 1830) (Pisces: Gerreidae) en la bahía de Cispatá, golfo de Morrosquillo, Caribe colombiano. Bachelor Dissertation, Universidad de los Andes, Bogotá.

Prahl, H.v. (1989) Manglares. Villegas Editores, Bogotá.

Prieto, M. (1988) Reporte de algunos cetáceos del Caribe colombiano. Boletín Facultad de Biología Marina 8: 30-40.

Ramos, R.M.A., Di Beneditto, A.P.M. and Lima, N.R.W. (2000) Growth parameters of Pontoporia blainvillei and Sotalia fluviatilis (Cetacea) in northern Rio de Janeiro, Brazil. Aquatic Mammals 26: 65-75.

Reeves, R.R., Smith, B.D., Crespo, E.A. and Notarbartolo Di Sciara, G. (2003). Dolphins, Whales and Porpoises: 2002-2010 Conservation Action Plan for the World's Cetaceans. IUCN/SSC Cetacean Specialist Group. IUCN, Gland, Switzerland and Cambridge, UK.

Rosas, F.C.W. (2000) Interações com a pesca, mortalidade, idade, reprodução e crescimento de Sotalia fluviatilis e Pontoporia blainvillei no litoral Sul do estado de São Paulo e litoral do estado do Paraná, Brasil. Doctoral Thesis, Universidade Federal do Paraná, Curitiba.

Rueda, M. and Defeo, O. (2003) Linking fishery management and conservation in a tropical estuarine lagoon: Biological and physical effects of an artisanal fishing gear. Estuarine, Coastal and Shelf Science 56: 1-9.

Santos, M.C. de O., Acuña, L.B. and Rosso, S. (2001) Insights on site fidelity and calving intervals of the marine tucuxi dolphin (Sotalia fluviatilis) in southeastern Brazil. Journal of the Marine Biological Association, UK 81: 1049-1052.

Shane, S.H. (1990) Behavior and ecology of the bottlenose dolphin at Sanibel Island, Florida. Pages 245-266 in Leatherwood, S. and Reeves, R.R. (Eds) The bottlenose dolphin. Academic Press, San Diego.

Sierra, P.C. (1995) Biología, ecología y algunos aspectos pesqueros del róbalo Centropomus undecimalis (Bloch 1772) (Pisces: Centropomidae) en la bahía de Cispatá, Golfo de Morrosquillo, Caribe colombiano. Bachelor Dissertation, Universidad Jorge Tadeo Lozano, Bogotá. 